------ Raf. J. Sci., Vol. 23, No.1 pp 91-103, 2012------

\title{
The Novel Use of Processed Ninivite-Kaolin Mixture Part 2: Cadmium and Lead Removal from Their Effluents
}

\author{
Moath H. Mustafa \\ College of Environmental \\ Sciences and Technology
}

University of Mosul
Tariq A. Mahmoud

Department of Civil

Engineering

College of Engineering

University of Mosul

\author{
Wadala A. Bashir \\ Department of Chemistry \\ College of Science \\ University of Mosul
}

(Received 4/ 4/2011; Accepted 5/9/2011)

\begin{abstract}
Cadmium and lead effluents had been treated with a (1:1) mixture of low grade ninivite $(\mathrm{N})$ and Kaolin $(\mathrm{K})$. Before use, the mixture is treated only with a $10 \%$ brine solution and found to be effective for the removal of $85 \% \mathrm{Cd}$ ( at a maximum concentration of $200 \mathrm{mg} / \ell$ ) at a $\mathrm{pH}$ of 11.5 and $90 \% \mathrm{~Pb}$ (at a maximum concentration of $1000 \mathrm{mg} / \ell$ ) at a $\mathrm{pH}$ 7.0. The results were compared using Dowex-50X, as a typical cation exchanger and activated carbon (charcoal), as an ideal adsorbent and found to be satisfactory.
\end{abstract}

Keywords: ninivite and kaolin; $\mathrm{S}(\mathrm{N}+\mathrm{K})$, cadmium and lead removal; effluents.

\section{الجيدفي إمكلنية الستخدلمزميجمن النينليت والكاؤلين

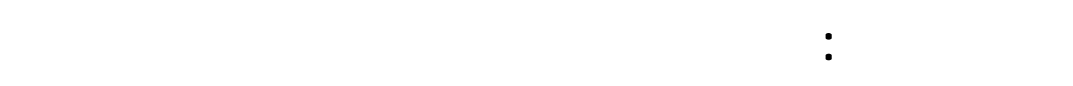

\section{ll}

عولجت مطروحلت الكاميوم والرصاص مع مزيج من (1:1) من النينفايت ذي القاوة الوطئة

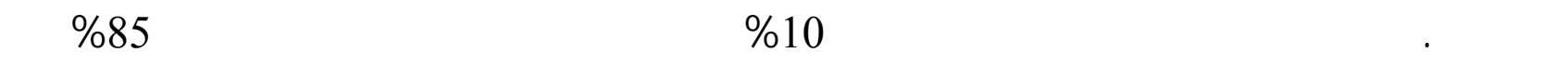

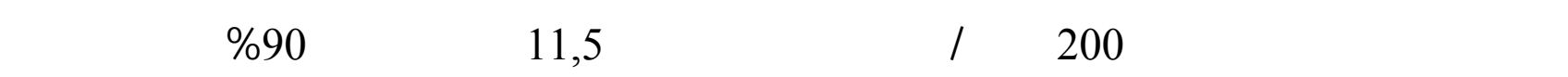

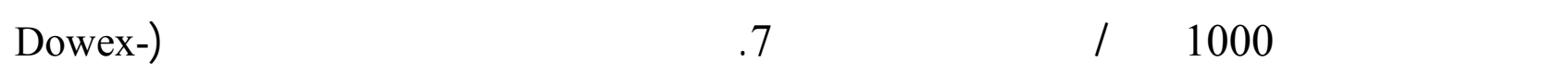
(50X والفهم الفعل كماة ممدصة واقد كانت النتائج مقنعة .

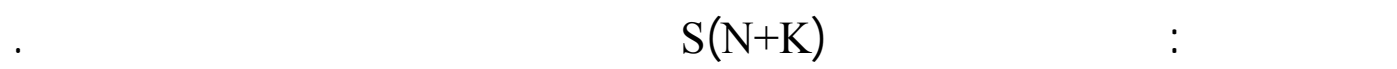

\section{INTRODUCTION}

Cadmium is a highly toxic non-essential metal. Artificially, the source of cadmium includes different industrial uses, recently in corrosion prevention, polymer stabilization, electronics and pigment applications (WHO, 1997). Cadmium concentrations of 0.1 to 1.0 
$\mathrm{mg} / \ell$, are typical in discharges of chemicals, allied products, leather products, electric, gas and sanitary industries, (Allen et al., 1998). Cadmium concentration discharges above 1 $\mathrm{mg} / \ell$ are typical of the fabricated metal products, electronic and electric equipments (Stanitski et al., 2000). Also (Stanitski et al., 2000), has stated that Cd should not exceed $0.005 \mathrm{mg} / \ell$ in drinking water. Lead is also a highly toxic heavy metal. Its accumulation in man body may reach a vital dosage. Lead has a wide uses where it can be found everywhere; it is a cumulative poison, and most of its salts are sparingly soluble, (Alloway and Ayres, 1997; Wang and Tessier, 2002; Muni, 2001). Sources of lead can be both natural (Abdul-Al-Noor, 2000), and artificial (Lide, 1997-1998). It could be assumed as the most toxic metal distributed in nature in comparison with cadmium and other heavy metals, due to the wide application and uses but it is less toxic than mercury (Lindeburg, 2001). Lead levels in cities are ten times than those found in the countryside (Al-Asad and Foza, 2000). Maximum concentration level in drinking water should never exceed $0.015 \mathrm{mg} / \ell$ and the target is to be zero. EPA has established a maximum contaminant level goal of zero, even though lead is not a carcinogen (Lindeburg, 2001).

Certain clays have the ability to hold heavy metals (Al-Mallah, 1999). Accordingly, local raw materials are examined and used for the removal of both cadmium and lead and these are ninivite ( $\mathrm{N}$ a silica rich rock, taken from Humeira south Mosul city), and kaolin (K, from Duekhla location, Ga'ara, depression western desert of Iraq). Both materials have shown the ability to hold heavy metals from their effluents by any means of adsorption, absorption and/or ion exchange (Al-Naqib and Mustafa, 1998; Mustafa, 2005). Chemical compositions of the materials used are given in Table 1.

Table 1: Chemical composition* of ninivite and kaolin.

\begin{tabular}{|c|c|c|}
\hline Components, $\%$ & Ninivite & Kaolin \\
\hline $\mathbf{S i O}_{\mathbf{2}}$ & 56.50 & 47.93 \\
\hline $\mathbf{T i O}_{\mathbf{2}}$ & N.D & N.D \\
\hline $\mathbf{A l}_{\mathbf{2}} \mathbf{O}_{\mathbf{3}}$ & 1.11 & 35.78 \\
\hline $\mathbf{F e}_{\mathbf{2}} \mathbf{O}_{\mathbf{3}}$ & 0.89 & 1.04 \\
\hline $\mathbf{C a O}$ & 15.79 & 1.13 \\
\hline $\mathbf{M g O}$ & 0.12 & 3.04 \\
\hline $\mathbf{N a}_{\mathbf{2}} \mathbf{O}$ & N.D & 0.01 \\
\hline $\mathbf{K}_{\mathbf{2}} \mathbf{O}$ & N.D & 0.02 \\
\hline $\mathbf{P}_{\mathbf{2}} \mathbf{O}_{\mathbf{5}}$ & N.D & 0.03 \\
\hline $\mathbf{S O}_{\mathbf{3}}{ }^{-2}$ & 17.30 & 0.25 \\
\hline $\mathbf{C l}^{-}$ & N.D & 0.51 \\
\hline Loss on ignition & 8.25 & 10.43 \\
\hline $\mathbf{C d}^{+2}$ & N.D & N.D \\
\hline $\mathbf{P b}^{+\mathbf{2}}$ & N.D & N.D \\
\hline $\mathbf{H g}^{+2}$ & N.D & N.D \\
\hline
\end{tabular}

*Performed as described in Jeffery and Hutchison (1981), N.D. $=$ not detected.

The aim of the present work is to examine the capability of a mixture of ninivite and kaolin to remove cadmium and lead from their effluents. In the meantime, ninivite has an 
immense surface area $\left(800 \mathrm{~m}^{2} / \mathrm{g}\right)$ and other useful physical properties of porosity $(70.5 \%)$ and a permeability of $6.8 \times 10^{-5} \mathrm{~cm} / \mathrm{sec}$ (Al-Naqib and Mustafa, 1998; Al-Najjar, 2000; AlUbaidy, 2004).

\section{Reagents}

\section{EXPERIMENTAL}

Chemicals and solutions: Chemicals used are of the highest purity available.

Ninivite and kaolin: ninivite and kaolin are crushed to 0.3-1.2 mm (35-150 mesh), which has been confirmed by the D10 test (Kiley, 1997). Before use, they are dried at $103-105^{\circ} \mathrm{C}$.

Dowex-50 X: This is a strong cation exchange resin (Dow chemical company), regenerated by treatment with $4 \%$ sodium chloride (Merck) solution. This was followed by washing several times with distilled water until chloride-free effluent is obtained. The regenerated resin is then air-dried and kept in a sealed pocket.

Activated carbon (charcoal): this is used as supplied by (B.D.H) and kept in oven at $103^{\circ} \mathrm{C}$.

Cadmium stock solution $(\mathbf{1 0 0 0} \mathbf{~ m g} / \mathfrak{l})$ : This solution is prepared by dissolving $2.1031 \mathrm{~g}$ of cadmium nitrate (B.D.H) in distilled water and diluting the volume to $1 \ell$ in a $1000-\mathrm{ml}$ volumetric flask. This solution is then transferred to a polyethylene bottle, (APHA, AWWA and WPCF, 1985). Standard solutions are prepared by diluting stock solution to $1000 \mathrm{ml}$ with distilled water in a volumetric flask. Less concentrated solutions are prepared by appropriate dilution of the standard cadmium solution.

Lead stock solution $(\mathbf{1 0 0 0} \mathbf{~ m g / \ell})$ : Such solution is prepared by dissolving $1.5985 \mathrm{~g}$ of lead nitrate (B.D.H) in distilled water and diluting the volume in a 1000-ml volumetric flask. This solution is then transferred to a polyethylene bottle, (APHA. AWWA. WPCF 1985). Working solutions $(100 \mathrm{ml})$ are prepared by diluting $100 \mathrm{ml}$ volume of the above stock solution to $1000 \mathrm{ml}$ with distilled water in a 1000-ml volumetric flask. Less concentrated solutions are prepared by appropriate dilution of the standard lead solution. "Needless to say that the stock solution has been used later directly for the high concentrations of 1000 $\mathrm{mg} / \ell^{\prime \prime}$.

Saturated lime solution: This solution is prepared by dissolving uncounted quantity of lime (quick lime), with distilled water, shaked several times and left for clarification then filtered to be used as a clear saturated solution of lime. Actually water dissolves only normally burned calcium oxide $(\mathrm{CaO})$; this solution is prepared weekly. Lime solution should be clear, filtration is necessary when it is turbid.

Brine solution 10\%: A $100 \mathrm{~g}$ of sodium chloride (B.D.H) in $1 \ell$.

Cadmium and lead determination: Both cadmium and lead experiments and determination had been run using atomic absorption which are mentioned in the apparatus used in this work.

\section{Apparatus}

The following apparatuses are used in the present work: 1. Shaker, 2. Electric Muffle Furnace, 3. pH meter, 4. PYE Unicam SP9 atomic absorption spectrophotometer.

Note: Calibrations were performed by measuring the absorption signal at $228.8 \mathrm{~nm}$ for $(\mathrm{Cd})$ and $217 \mathrm{~nm}$ for $(\mathrm{Pb})$. 


\section{Raw materials and its processing}

Processing of ninivite and kaolin (1:1) by weight is carried out by salting (S) using $10 \%$ brine solution and by heating to $600^{\circ} \mathrm{C}(\mathrm{A})$, in order to activate ion exchange and/or adsorption phenomena by forming or inducing some functional group prior for exchanging purposes which seem to be very important. New forms are $[(\mathrm{N}+\mathrm{K}), \mathrm{A}(\mathrm{N}+\mathrm{K}), \mathrm{S}(\mathrm{N}+\mathrm{K})$, $\mathrm{AS}(\mathrm{N}+\mathrm{K})]$. The removing efficiency of these mixtures was compared with Dowex-50 X, as a strong cationic exchange resin, and activated carbon (charcoal) as an ideal adsorbent. According to (Crear, 2001), lead forms hydroxo complexes as turbidity at pH 6.0 to 7.0, while cadmium formed turbid cloudy precipitate at a $\mathrm{pH}$ of $10.5-11.5$, using lime solution for $\mathrm{pH}$ adjustment, (Al-Asad and Foza, 2000; Dyer et al., 1997; Masschelein, 1992). Lead and cadmium colloid may precipitate and/or adsorb on the surface of the mineral raw materials (Boynton, 1980).

\section{RESULTS AND DISCUSSION}

In the preliminary experiments, cadmium and lead solutions were treated with saturated lime solution to remove as much as possible of these pollutants since point sources pollution are taken into consideration, which they reflect the high concentrations of the intended pollutants. Also, in the early investigation, experiments were performed at room temperature since the parameter is considered economic and previous studies (Mustafa, 2005) confirms that, which is logical from the adsorption point of view. Other parameters put into consideration in the present work are $\mathrm{pH}$, time, temperature and quantity of treatment raw materials (Al-Mallah, 1999; Dyer et al., 1997; Reddy and Reddy, 2003; Sullivan et al., 2000; Rashed, 2003; Liu et al., 2001; Krishnan and Anirudhan, 2003; Nagata et al., 2001). The pHs were already fixed on 7.0 and 11.5 for lead and cadmium, respectively due to turbidity formation at these values by lime solution. From economic point of view, room temperature was chosen. So time and amount of treatment materials should be examined. It is worthy to mention that experimentally it was found that 300 cycle/minute is useful for complete mixing, also particle size was 0.3-1.2 mm were used equivalent to ion exchange resins size, later on a size of $\leq 0.3 \mathrm{~mm}$ were considered, due to the fact of using the treated materials on fluid face, actually it is failed to work in column as a polisher. Finally, $50 \mathrm{ml}$ had been used for all samples, filtered after treatments prior to be determined by atomic absorption.

\section{Evaluation of different amount of $(\mathrm{N}+\mathrm{K})$ for the removal of $\mathrm{Cd}$ and $\mathrm{Pb}$}

To $50 \mathrm{ml}$ of both element nitrate solutions, different amounts of $(\mathrm{N}+\mathrm{K})$ had to be evaluated for its removal efficiency. Table (2) show the removal of $20 \mathrm{mg} \mathrm{Cd} / \ell$, at a $\mathrm{pH} 11$ 11.5 , and $100 \mathrm{mg} \mathrm{Pb} / \ell$ at a $\mathrm{pH} 7.0$ were chosen as a beginning.

Table 2: Evaluation of different amounts of $(\mathrm{N}+\mathrm{K})$ for the removal of $20 \mathrm{mg} \mathrm{Cd} / \ell$ at 11.0 $11.5 \mathrm{pH}$, and $100 \mathrm{mg} \mathrm{Pb} / \ell$ at $7.0 \mathrm{pH}$.

\begin{tabular}{|l|c|c|c|c|c|c|}
\hline weight of (N+K) mixture, $\mathbf{g}$ & 0.25 & 0.50 & 0.75 & 1.00 & 1.50 & 2.00 \\
\hline Residual concentration of $\mathbf{C d}$ (II) ions, $\mathbf{m g} / \boldsymbol{l}$ & N.D. & N.D & 1.0 & 1.2 & 1.5 & 3.0 \\
\hline Residual concentration of $\mathbf{P b}$ (II) ions, $\mathbf{m g} / \boldsymbol{l}$ & 15 & - & 13 & 13 & 13 & 13 \\
\hline
\end{tabular}


Particle size $=0.3-1.2 \mathrm{~mm}$, at room temperature $20-25{ }^{\circ} \mathrm{C}$, time $=1 \mathrm{hr}$ and mixing speed of 300 cycle/minute.

It can be seen that the most efficient removal takes place at lower amounts of the mixed raw materials and this is attributed to the high surface area of the processed material. However, when the amounts become above $0.5 \mathrm{~g}$, the efficiency slightly decreases and this may be attributed to agglomeration of the raw material. A weight of $0.25 \mathrm{~g}$ of mixed raw material is selected to use in the subsequent investigations.

\section{Effect of shaking time}

A (15-120)-minute shaking time has been tried for maximal removal of cadmium and lead ions from their solution. The time in the above interval was not critical (Table 3 ) and therefore any time between 15 and 90 minutes can be selected. The effect of shaking time of sample solutions of cadmium and lead ions with $(\mathrm{N}+\mathrm{K})$ are shown in Table 3 .

Table 3: Removal efficiency of $(\mathrm{N}+\mathrm{K})^{*}$ at different mixing times treating $20 \mathrm{mg} \mathrm{Cd} / \ell$ at 11.0-11.5 $\mathrm{pH}$, and $100 \mathrm{mg} \mathrm{Pb} / \ell$ at $7.0 \mathrm{pH}$.

\begin{tabular}{|l|c|c|c|c|c|}
\hline Time in minutes & 15 & 30 & 45 & 90 & 120 \\
\hline Residual conc. of $\mathbf{C d}$ (II) ions, $\mathbf{m g} / \boldsymbol{\ell}$ & 1.0 & 2.0 & 2.5 & 1.7 & 2.0 \\
\hline Residual conc. of $\mathbf{P b}$ (II) ions, $\mathbf{~ m g / \ell}$ & 15 & 14.5 & 15 & 14.5 & 25 \\
\hline
\end{tabular}

* $0.25 \mathrm{~g}$ amount of $(\mathrm{N}+\mathrm{K})$; $\mathrm{pH}$ of $\mathrm{Cd}$ (II) ions $(20 \mathrm{mg} / \ell)=11-11.5, \mathrm{pH}$ of $\mathrm{Pb}(100 \mathrm{mg} \mathrm{Pb} / \ell)=7.0$, particle size $=0.3-1.2 \mathrm{~mm}$, at room temperature $20-25{ }^{\circ} \mathrm{C}$ and mixing speed of 300 cycle/minute.

For conveniences, a 15-minute interval shaking time is chosen for further studies. The lower efficiency for $\mathrm{Pb}$ (II) removal at longer shaking time is assigned to desorption probably.

High concentrations of lead nitrate solution (Al-Mallah, 1999) could be used (100 to $500 \mathrm{mg} \mathrm{Pb} / \ell$ ), with two different types of mixtures in order to evaluate the holding capacity of both of them. Table (4) shows the differences between $(\mathrm{N}+\mathrm{K})$ and $\mathrm{A}(\mathrm{N}+\mathrm{K})$.

Table 4: Removal efficiency of $(\mathrm{N}+\mathrm{K})$ and $\mathrm{A}(\mathrm{N}+\mathrm{K})$.

\begin{tabular}{|c|c|c|}
\hline $\begin{array}{c}\text { Initial Concentration } \\
\text { of } \mathbf{P b} \text { (II) ions } \mathbf{m g} / \boldsymbol{\ell}\end{array}$ & $\begin{array}{c}\text { Residual concentration of } \mathbf{P b} \\
\text { (II) ions } \begin{array}{c}\text { mg/ } \boldsymbol{\ell} \text { after } \\
\text { treatment }\end{array}\end{array}$ \\
\cline { 2 - 3 } & (N+K) & $\mathbf{A}(\mathbf{N}+\mathbf{K})$ \\
\hline 100 & 45.0 & 60.0 \\
\hline 300 & 70.0 & 95.0 \\
\hline 500 & 90.0 & 100.0 \\
\hline
\end{tabular}

The wt of treatment materials $=0.25 \mathrm{~g}$, mixing time $=15 \mathrm{~min}$, $\mathrm{pH}=7.0$, room temperature, $20-25{ }^{\circ} \mathrm{C}$

mixing speed 300 cycle/minute, particle size of treatment materials is $0.3-1.2 \mathrm{~mm}$. 
The results in Table (4) show clearly that the mixture of $(\mathrm{N}+\mathrm{K})$ gives better results than $\mathrm{A}(\mathrm{N}+\mathrm{K})$, and both are capable of removing high concentrations of lead. Another range of concentration of lead nitrate solution could be used ( 200 to $1000 \mathrm{~Pb} \mathrm{mg} / \ell$ ), with $0.25 \mathrm{~g}$ of treatment materials, 15 minutes time, and room temperature shown in Table.

\section{Impact of processed $(\mathbf{N}+\mathbf{K})$}

Running a new experiment using high concentrations of both $\mathrm{Cd}$ and $\mathrm{Pb}$ considering the optimum conditions found in the previous experiments. Also the application of processed $(\mathrm{N}+\mathrm{K})$ mixtures which are $\mathrm{A}(\mathrm{N}+\mathrm{K}), \mathrm{S}(\mathrm{N}+\mathrm{K})$, and $\mathrm{AS}(\mathrm{N}+\mathrm{K})$ to find out their removal efficiencies, which are shown in Table (5).

Table 5: Effect of processed $(\mathrm{N}+\mathrm{K}) *$ and standard materials on the removal efficiency of both $\mathrm{Cd}$ (II) and $\mathrm{Pb}$ (II) ions.

\begin{tabular}{|c|c|c|c|c|c|c|c|c|c|c|c|c|c|}
\hline \multirow{2}{*}{\multicolumn{2}{|c|}{$\begin{array}{c}\text { Initial } \\
\text { concentration } \\
\mathrm{mg} / \ell\end{array}$}} & \multicolumn{12}{|c|}{ Residual Cd and $\mathrm{Pb}$ (II) ions concentrations, $\mathrm{mg} / \ell$} \\
\hline & & \multicolumn{2}{|c|}{$\mathbf{A S}(\mathbf{N}+\mathbf{K})$} & \multicolumn{2}{|c|}{$\mathbf{S}(\mathbf{N}+\mathbf{K})$} & \multicolumn{2}{|c|}{$\mathbf{A}(\mathbf{N}+\mathbf{K})$} & \multicolumn{2}{|c|}{$(\mathbf{N}+\mathbf{K})$} & \multicolumn{2}{|c|}{ Charcoal } & \multicolumn{2}{|c|}{$\begin{array}{c}\text { Dowex- } \\
50 X\end{array}$} \\
\hline Cd & $\mathbf{P b}$ & Cd & $\mathbf{P b}$ & Cd & $\mathbf{P b}$ & Cd & $\mathbf{P b}$ & $\mathbf{C d}$ & $\mathbf{P b}$ & Cd & $\mathbf{P b}$ & Cd & $\mathbf{P b}$ \\
\hline 40 & 200 & 13 & 46 & 12 & 11 & 12 & 23 & 8 & 18 & 40 & 115 & 40 & 123 \\
\hline 80 & 400 & 14 & 78 & 13 & 14 & 12 & 25 & 11 & 27 & 80 & 165 & 80 & 165 \\
\hline 120 & 600 & 44 & 95 & 17 & 15 & 14 & 30 & 12 & 51 & 120 & 225 & 120 & 158 \\
\hline 160 & 800 & 25 & 220 & 21 & 13 & 12.5 & 31 & 11 & 170 & 160 & 318 & 160 & 180 \\
\hline 200 & 1000 & 46 & 460 & 21 & 21 & 13 & 38 & 12 & 360 & 200 & 365 & 200 & 170 \\
\hline
\end{tabular}

* A $0.25 \mathrm{~g}$ amount of $(\mathrm{N}+\mathrm{K})$, its particle size $=0.3-1.2 \mathrm{~mm}, \mathrm{Cd}$ (II) ions $\mathrm{pH}$ is $11-11.5, \mathrm{pH}$ of $\mathrm{Pb}$ (II) ions is 7.0 , room temperature $20-25^{\circ} \mathrm{C}$, time $=15$ minutes and mixing speed of 300 cycle/minute.

The results in Table (5) show that $(\mathrm{N}+\mathrm{K})$ mixed raw mineral material gives the highest removal efficiency for $\mathrm{Cd}$ while for $\mathrm{Pb}$ solutions, better removal is by using $\mathrm{S}(\mathrm{K}+\mathrm{L})$.

Application of the above facts on a chromatographic column (to be used as a polishing filter in water treatment plant) has not been possible due to the following observations:

- A bit of swelling has been noticed due to the ability of ninivite to absorb water molecules (it may exceed 100\%).

- No filtration has been possible, when column filled only with one of the mixtures $(\mathrm{N}+\mathrm{K}), \mathrm{A}(\mathrm{N}+\mathrm{K}), \mathrm{S}(\mathrm{N}+\mathrm{K})$, or $\mathrm{AS}(\mathrm{N}+\mathrm{K})$.

Due to the above facts, $(\mathrm{N}+\mathrm{K})$ and its processed materials were milled to pass $0.3 \mathrm{~mm}$ to be used as a coagulant. Instead of using it as a bed in column.

The new condition of a particle size $<0.3 \mathrm{~mm}$ accompanied with increasing the surface area which needs a further investigations. Table (6) show treatment materials weight evaluation. 
Table 6: The removal efficiency using different weights of $(\mathrm{N}+\mathrm{K})$ material of a particle size passing $0.3 \mathrm{~mm}$ sieve and a concentration of $100 \mathrm{mg} / \ell$, for both $\mathrm{Cd}$ and $\mathrm{Pb}$.

\begin{tabular}{|l|c|c|c|c|c|c|}
\hline g, weight of (N+K) & 0.05 & 0.10 & 0.15 & 0.20 & 0.25 & 0.50 \\
\hline Residual conc. of Cd (II) ions mg/l & 95 & 31 & 32 & 30 & 30 & 29 \\
\hline Residual conc. of $\mathbf{P b}$ (II) ions $\mathbf{~ m g / \ell}$ & 14 & 7.2 & 7.0 & 7.0 & 7.5 & 6.9 \\
\hline
\end{tabular}

Particle size passing 0.3 , at room temperature $20-25^{\circ} \mathrm{C}$, time $=15$ minute, mixing speed of 300 cycle $/$ minute, $\mathrm{pH}$ of $100 \mathrm{mg} / \ell \mathrm{Cd}(\mathrm{II})$ ions $=11-11.5, \mathrm{pH}$ of $100 \mathrm{mg} / \ell \mathrm{Pb}$ (II) ions $=7.0$.

The above table reflects clearly that the weight $0.1 \mathrm{~g}$ gives similar results compared with higher amounts and it could be considered as optimum amount.

\section{Effect of shaking time on removal efficiency}

The effect of mixing time of $(\mathrm{N}+\mathrm{K})$ mineral raw material with the solutions of both $\mathrm{Cd}$ (II) ions and $\mathrm{Pb}$ (II) ions (100 $\mathrm{mg} / \ell)$ have been re-examined. The experimental data are shown in Table (7).

Table 7: The Removal efficiency of using $0.1 \mathrm{~g}(\mathrm{~K}+\mathrm{L})$ mixture.

\begin{tabular}{|l|c|c|c|c|}
\hline Time, minute & 5 & 10 & 15 & 30 \\
\hline Residual conc. of Cd (II) ions mg/ $\ell$ & 70 & 15 & 15 & 15 \\
\hline Residual conc. of $\mathbf{P b}$ (II) ions mg/ $\ell$ & 16 & 7.0 & 7.2 & 7.0 \\
\hline
\end{tabular}

$\mathrm{pH}$ of $100 \mathrm{mg} / \ell \mathrm{Cd}$ (II) ions $=11-11.5$, and $\mathrm{pH}$ of $100 \mathrm{mg} / \ell, \mathrm{Pb}=7.0$ particle size passing 0.3 , at room temperature $20-25^{\circ} \mathrm{C}$, mixing speed of 300 cycle/minute,

Table (7) clearly shows that 10 minute mixing time has proven optimum. Furthermore, the effect of processed $(\mathrm{N}+\mathrm{K})$ raw material on their removal efficiency of $\mathrm{Cd}$ and $\mathrm{Pb}$ (II) ions from their solutions has been examined. The experimental data are given in Table (8).

\section{Removal efficiency using processed mixed $(\mathbf{N}+\mathbf{K})$}

The new optimal conditions of the removal efficiency clearly shown in Table (8) results for both cadmium and lead considering: 1.weight of $0.1 \mathrm{~g}$ treatment material, 2.10minute mixing time, 3. using different processed mixed $(\mathrm{N}+\mathrm{K})$, 4. particle size passing through $0.3 \mathrm{~mm}, 5$. room temperature, $6 . \mathrm{pH}=7.0$ for $\mathrm{Pb}$ and 11.5 for $\mathrm{Cd}, 7$. mixing speed of 300 cycle/minute. These conditions are applied to considered for both cadmium and lead nitrate solutions of concentrations (40-200) $\mathrm{mg} \mathrm{Cd} / \ell$ and (200-1000) $\mathrm{mg} \mathrm{Pb} / \ell$, and as follows: 
Table 8: Removal efficiency of different mixtures, and standard materials considering the new conditions.

\begin{tabular}{|c|c|c|c|c|c|c|c|c|c|c|c|c|c|}
\hline \multirow{2}{*}{\multicolumn{2}{|c|}{$\begin{array}{c}\text { Initial } \\
\text { concentration } \\
\mathrm{mg} / \ell\end{array}$}} & \multicolumn{12}{|c|}{ Residual $\mathrm{Cd}$ and $\mathrm{Pb}$ (II) ions concentration $\mathrm{mg} / \ell$ after treatment } \\
\hline & & \multicolumn{2}{|c|}{$\mathbf{A S}(\mathbf{N}+\mathrm{K})$} & \multicolumn{2}{|c|}{$\mathbf{S}(\mathbf{N}+\mathbf{K})$} & \multicolumn{2}{|c|}{$\mathbf{A}(\mathbf{N}+\mathbf{K})$} & \multicolumn{2}{|c|}{$(\mathbf{N}+\mathbf{K})$} & \multicolumn{2}{|c|}{ Charcoal } & \multicolumn{2}{|c|}{$\begin{array}{l}\text { Dowex- } \\
\text { 50X }\end{array}$} \\
\hline Cd & $\mathbf{P b}$ & Cd & $\mathbf{P b}$ & Cd & $\mathbf{P b}$ & Cd & $\mathbf{P b}$ & Cd & $\mathbf{P b}$ & Cd & $\mathbf{P b}$ & Cd & $\mathbf{P b}$ \\
\hline 40 & 200 & 9 & 26 & 7 & 5 & 11 & 15 & 9 & 10 & 40 & 105 & 40 & 215 \\
\hline 80 & 400 & 12 & 52 & 10 & 6 & 13 & 14 & 15 & 13 & 80 & 176 & 80 & 315 \\
\hline 120 & 600 & 25 & 93 & 20 & 7 & 20 & 16 & 22 & 27 & 120 & 235 & 120 & 415 \\
\hline 160 & 800 & 36 & 133 & 28 & 8 & 30 & 18 & 35 & 40 & 160 & 335 & 160 & 550 \\
\hline 200 & 1000 & 56 & 150 & 39 & 9 & 55 & 18 & 63 & 50 & 200 & 450 & 200 & 645 \\
\hline
\end{tabular}

The above results in Table (8) show that $\mathrm{S}(\mathrm{K}+\mathrm{L})$ mixture gives the highest removal efficiency. It reflects clearly that the weight of $0.1 \mathrm{~g}$ more or less gives similar results compared with others and it could be considered as optimum amount. It is also shown that lower amounts of $\mathrm{S}(\mathrm{N}+\mathrm{K})$ are more efficient. This might be explained as the extent of adsorption of the semi-colloidal compounds of both cadmium and lead (II) ions will increase, as compared with the less available surfaces at higher amounts of $(\mathrm{N}+\mathrm{K})$, probably due to agglomeration. For the subsequent experiments, $0.25 \mathrm{~g}$ of the mixed $(\mathrm{N}+\mathrm{K})$ is used.

An additional advantages of the above treatment mainly at high $\mathrm{pH}$ are suppression of hardness (Al-Najjar, 2000), eliminate odor, taste and color, due to organic load elimination (Al-Naqib and Mustafa, 1998), this in addition to adsorption and/or absorption of halogenated hydrocarbons (Al-Naqib and Mustafa, 1998). Also, it aids in the formation of surfaces capable of adsorption ( Crear, 2001).

The mixture of $\mathrm{S}(\mathrm{N}+\mathrm{K})$ displays clearly that the removal efficiency of cadmium $(>85 \%)$ and for lead $(>95 \%)$ weight of $0.1 \mathrm{~g} \mathrm{~S}(\mathrm{~N}+\mathrm{K}) / 50 \mathrm{ml}$ of heavy metal samples for each heavy metal solutions which is equivalent to $2 \mathrm{~g} / \ell\left(2 \mathrm{~kg} / \mathrm{m}^{3}\right)$.

\section{Field work applications}

Samplings from different channels within Mosul city had been done. Unfortunately, a direct reading of cadmium and lead (after sample filtration) couldn't be done due to non significant readings. To increase the sensitivity, samples were digested with $\mathrm{HNO}_{3}(500 \mathrm{ml}$ sample $+10 \mathrm{ml}$ concentrated $\mathrm{HNO}_{3}$ ) was necessary for, $\mathrm{Cd}$ and $\mathrm{Pb}$ detection according to (Meeravali and Kumar, 2000). The removal efficiency in different channels is shown in Table (9).

Table 9: Results of cadmium concentration in $\mathrm{mg} / \ell$ from different channels within Mosul City.

\begin{tabular}{|c|c|c|c|c|c|c|c|c|}
\hline \multirow{3}{*}{$\begin{array}{l}\text { Treatments of } \mathrm{Cd} \text { and } \mathrm{Pb} \\
\text { field samples }\end{array}$} & \multicolumn{8}{|c|}{ Residual $\mathrm{Cd}$ and $\mathrm{Pb} \mathrm{mg} / \mathrm{\ell}$} \\
\hline & \multicolumn{2}{|c|}{ Al-Khosar } & \multicolumn{2}{|c|}{$\mathbf{A q a b}^{\mathbf{a}}$} & \multicolumn{2}{|c|}{ Al-Seeb } & \multicolumn{2}{|c|}{ Danfilly $^{b}$} \\
\hline & $\mathbf{C d}$ & $\mathbf{P b}$ & Cd & $\mathbf{P b}$ & Cd & $\mathbf{P b}$ & Cd & $\mathbf{P b}$ \\
\hline Raw sample & 5 & 22 & 8 & 12 & 3 & 30 & 8 & 18 \\
\hline pH adjustment by lime & 2 & 17 & 3 & 9 & 1 & 16 & 3 & 8 \\
\hline Liming and $(\mathrm{N}+\mathrm{K})$ & N.D & 13 & N.D & 6 & N.D & 14 & N.D & 5 \\
\hline Liming and $A(N+K)$ & N.D & 11 & N.D & 4 & N.D & 11 & N.D & 4 \\
\hline Liming and $\mathrm{S}(\mathrm{N}+\mathrm{K})$ & N.D & 6 & N.D & 3 & N.D & 7 & N.D & 3 \\
\hline Liming and $\mathrm{AS}(\mathrm{N}+\mathrm{K})$ & N.D & 8 & N.D & 4 & N.D & 9 & N.D & 2 \\
\hline
\end{tabular}

$\mathrm{a}=$ Serving the right bank industrial zone, $\mathrm{b}=$ Serving the left bank industrial zone. 
The results in the above table show clearly that liming was fair enough to remove cadmium, followed with any type of treatment mentioned in the above table, while lead couldn't be eliminated completely even with any treatment materials after liming. Lead is also not necessarily to be found in contact with industrialized zone disposals. This reflects the wide spreading of lead uses, where the concentration of lead (II) ions in Al-Khosar river and Al-Seeb channels effluents show higher than Aqab and Danfilly channels effluents. The latter are passing through industrialized areas in both sides of Mosul city. Actually, AlKhosar catchments areas are more than $700 \mathrm{~km}^{2}$, receiving 2/3 the waste water of the left bank of Mosul city, (Mustafa, 2009), while Al-Seeb is affected by a cumulative of lead coming from the consumptions of lead acetate, which had been used in sugar analyses at Mosul sugar factory, since 1959 (Mustafa, 2002), Fig. 1.

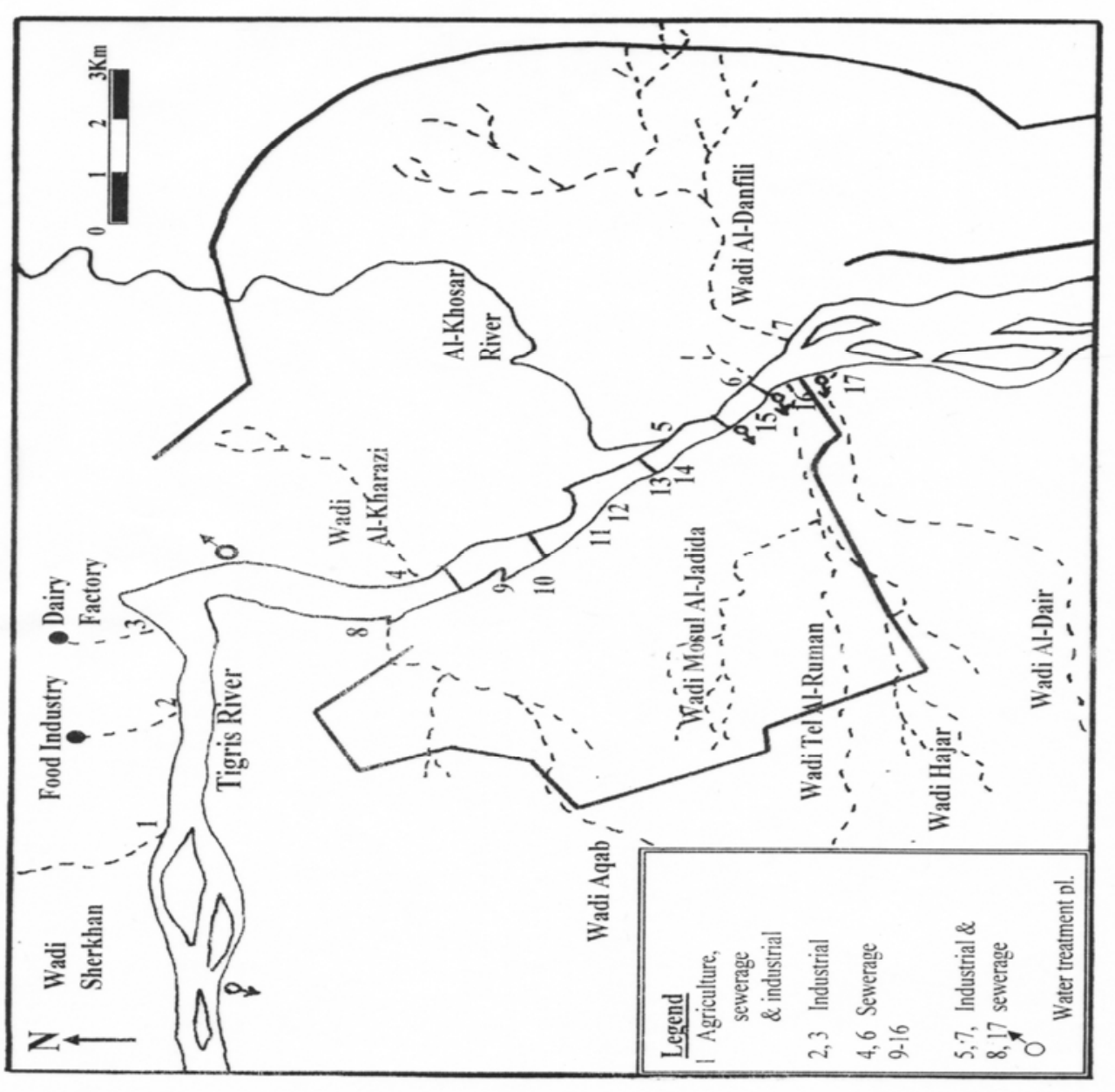




\section{Comparison of methods}

The present work has been compared with related recent studies and the data are shown in Table (10).

Table 10: Comparison between different heavy metals removal processes.

\begin{tabular}{|c|c|c|c|c|c|c|c|c|}
\hline \multirow{2}{*}{$\begin{array}{l}\text { Metal } \\
\text { (II) } \\
\text { ions }\end{array}$} & \multirow[t]{2}{*}{ Removal by } & \multirow{2}{*}{$\begin{array}{c}\text { Removal } \\
\text { mechanism }\end{array}$} & \multicolumn{4}{|c|}{ Experimental conditions } & \multirow{2}{*}{$\begin{array}{c}\% \\
\text { Removal }\end{array}$} & \multirow[t]{2}{*}{ Reference } \\
\hline & & & pH & Time & $\begin{array}{c}\text { Temp., } \\
\text { C }\end{array}$ & $\mathbf{Q t} / \mathbf{l}$ & & \\
\hline $\mathrm{Pb}^{(1)}$ & \multirow{2}{*}{$\begin{array}{l}\text { Magnesium oxide } \\
\text { coated with poly- } \\
\text { meric media }\end{array}$} & \multirow[t]{2}{*}{ Adsorption } & $>6.0$ & $\begin{array}{c}30 \\
\min \end{array}$ & \multirow[t]{2}{*}{$\begin{array}{l}\text { Out door } \\
\text { temp. }\end{array}$} & 5 & $>50$ & \multirow[t]{2}{*}{ Liu 2001} \\
\hline $\mathrm{Cd}^{(1)}$ & & & 10 & $5 \mathrm{hr}$ & & 5 & $>90$ & \\
\hline $\mathrm{Cd}^{(1)}$ & $\mathrm{S}(\mathrm{K}+\mathrm{L})$ & $\begin{array}{l}\text { Ion exchange } \\
\& \text { adsorption }\end{array}$ & 11.5 & $\begin{array}{c}10 \\
\min \end{array}$ & $20-25$ & 2 & $>85$ & \multirow[t]{2}{*}{$\begin{array}{l}\text { Present } \\
\text { work }\end{array}$} \\
\hline $\mathrm{Pb}^{(1)}$ & $\mathrm{S}(\mathrm{K}+\mathrm{L})$ & $\begin{array}{l}\text { Adsorption \& } \\
\text { ion exchange }\end{array}$ & 7.0 & $\begin{array}{c}10 \\
\min \end{array}$ & $20-25$ & 2 & $>90$ & \\
\hline $\mathrm{Cd}^{(1)}$ & $\begin{array}{l}\text { Clay mineral \& } \\
\text { amorphous } \\
\text { aluminosilicates }\end{array}$ & $\begin{array}{l}\text { Adsorption \& } \\
\text { ion exchange }\end{array}$ & $6-6.5$ & $24 \mathrm{hr}$ & 25 & 5 & $\begin{array}{l}\text { Not } \\
\text { mentione } \\
\text { d }\end{array}$ & $\begin{array}{c}\text { Sullivan et } \\
\text { al., } 2000\end{array}$ \\
\hline $\mathrm{Cd}^{(2)}$ & $\begin{array}{c}\text { Sulfurized carbon } \\
\text { activated by } \\
\text { steam }\end{array}$ & Adsorption & $5-9$ & $5 \mathrm{hr}$ & $30-60$ & 2 & 90 & $\begin{array}{c}\text { Krishnan \& } \\
\text { Anirudhan2 } \\
003\end{array}$ \\
\hline $\begin{array}{l}\mathrm{Cd} \\
\mathrm{Pb}\end{array}$ & $\begin{array}{l}\mathrm{ZrPO}_{4} \text { grafted in } \\
\text { silica gel surface }\end{array}$ & Adsorption & 4.5 & $15 \mathrm{~min}$ & $20-25$ & 4 & $\begin{array}{c}\text { Not } \\
\text { mentione } \\
d\end{array}$ & $\begin{array}{l}\text { Nagata et } \\
\text { al.,2001 }\end{array}$ \\
\hline \multirow[t]{2}{*}{$\mathrm{Pb}$} & \multirow{2}{*}{$\begin{array}{c}\text { Stones of peach \& } \\
\text { apricot }\end{array}$} & \multirow[t]{2}{*}{ Adsorption } & 7.0 & $5 \mathrm{hr}$ & \multirow[t]{2}{*}{$20-25$} & 40 & 99.4 & \multirow{2}{*}{$\begin{array}{l}\text { Rashed } \\
2003\end{array}$} \\
\hline & & & 6.5 & $\begin{array}{l}24 \mathrm{hr} \\
1-5 \mathrm{hr}\end{array}$ & & 10 & $\begin{array}{l}99.4 \\
99.2\end{array}$ & \\
\hline $\mathrm{Pb}$ & Karnikite & Adsorption & 7.0 & $48 \mathrm{hr}$ & $20-40$ & 10 & 99.0 & $\begin{array}{c}\text { Al-Mallah } \\
1999\end{array}$ \\
\hline $\begin{array}{l}\mathrm{Pb}^{(4)} \\
\mathrm{Cd}^{(5)}\end{array}$ & $\begin{array}{c}\text { Polystyrene- } \\
\text { supported } \\
\text { chelating polymer } \\
\text { resin }\end{array}$ & $\begin{array}{l}\text { Ion exchange } \\
\text { chelating or } \\
\text { adsorption or } \\
\text { both }\end{array}$ & $\begin{array}{c}10 \\
6\end{array}$ & $\begin{array}{l}1 \mathrm{hr} \\
1 \mathrm{hr}\end{array}$ & $25-30$ & $\begin{array}{l}27- \\
133\end{array}$ & $50-60$ & $\begin{array}{c}\text { Reddy \& } \\
\text { Reddy } 2003\end{array}$ \\
\hline $\begin{array}{l}\mathrm{Pb}^{(6)} \\
\mathrm{Cd}^{(7)}\end{array}$ & Zeolite $^{(8)}$ & Ion exchange & 5.0 & $1 \mathrm{hr}$ & $20-25$ & 1 & 96.4 & $\begin{array}{c}\text { Dyer et al., } \\
1997\end{array}$ \\
\hline
\end{tabular}

1.mainly as nitrate, 2 .initial concentration $=0.50-4.0 \mathrm{mg} \mathrm{Cd} / \ell, 3$.processed from sugar cane bagasse pith which may work by any means of adsorbent, absorbent or ion exchange), adsorbent dose 20 to $100 \mathrm{mg} / \ell$, also it is an endothermic reaction process of $18.28 \mathrm{KJ} / \mathrm{mol}$., 4. dose $=10-13 \mathrm{mg} / \mathrm{g}$, 5 . dose $=2-5 \mathrm{mg} / \mathrm{g}, 6$. concentration $=97 \mathrm{mg} / \ell, 7$. concentration $=77 \mathrm{mg} / \ell$., 8 . Zeolite are prepared from fly ashes which mainly aluminosilicate.

From the data in Table (10), the following conclusions can be drawn:

1. The $\mathrm{pH}$ of the medium of effluent ranges from 6-11, i.e., neutral to alkaline. In the present work, a $\mathrm{pH}$ of 7-11.5 has been found optimal for maximum removal. This $\mathrm{pH}$ adjustment can simply be accomplished using the cheap and available lime solution in contrast to the more cost-effective sodium hydroxide solution (Dyer, 1999). 
2. The shortest time (in minute) for performing heavy metals removal has been in the present work as compared to the much longer periods 5, 24 and $48 \mathrm{hrs}$ in other studies (Mustafa, 2009). The exception of (Nagata et al., 2001), 15-minute time is that it needs twice the weight of treatment material, which is costly to prepare $\mathrm{ZrPO}_{4}$ grafted in silica gel. 3. Most processes including the present work considered room temperature which is beneficial from the economic point of view.

4. The local availability of the present mineral raw materials and also the relatively small amount used is a prime target.

5. The removal efficiency gained in the present work rivals the highest when compared with others, in spite of using high concentration of heavy metals. This in addition to the following:

- $\quad$ treatment materials are found locally in huge quantity and are cheap, easy to handle and transport.

- $\quad$ it may need some sort of processing which is easy to practice and not costly, (i.e. milling, salting, heating, liming and carbonation), in a country where the construction equipment are working and available, with plenty of salt, limestone and fuel for lime production all are cheap and available. In the meantime lime kilns are working in both private and governorate sectors.

The above distinguished characteristics of the present process for the removal of heavy metals from their effluents will promote it for a pilot-plant design.

\section{CONCLUSION}

The effect of various parameters related to the holding capacity of the mixed raw mineral $(\mathrm{N}+\mathrm{K})$ materials has been tested. The experimental investigations have shown that the holding capacity of the mixed $(\mathrm{N}+\mathrm{K})$ is a function of many variables such as; amount of treatment material, $\mathrm{pH}$, temperature, time of mixing and processing pattern. The efficiency removal of $\mathrm{S}(\mathrm{N}+\mathrm{K})$ has been applied to the removal of cadmium and lead from channels and tributaries which are used as sewerage systems. All types of effluents are ended to Tigris river, including industrial, agricultural, runoff effluents discharges, assuming the river as a big sink. The ultimate results verified the promotion of the above mentioned raw materials to the status of most promising rivals.

\section{RECOMMENDATION}

1. Heavy metals discharge to environment should be absolutely stopped, so its removal from their effluents is a MUST.

2. Ninivite and kaolin is a promising local raw materials, which can be used for heavy metals removals, alone or after processing.

3. Further types of processing are necessary and trials to remove different type of heavy metals are necessary too. 


\section{REFERENCES}

Abdul Al-Noor, A. (2000). "Environmental Pollution, Soil and Plant". Dar Al-Nasher LeLJamiate, Cairo, pp.57-59, 63-64, 67-69, (Arabic).

Al-Asad, B.H.; Munim, Foza, M. (2000). Level of lead in the blood of factories in Syria, Arabic J. Pharm. Sci., Damascus, 1(2), 14-18, (Arabic).

Allen, H. E.; Garrison, A. W. ; Luther III, G. W., Editors (1998). "Metals in Surface Waters", Ann Arbor Press, U.S.A., pp. 44, 46, 52.

Alloway, B. J.; Ayres, D. C. (1997). "Chemical Principles of Environmental Pollution", 2nd edn., Chapman and Hall, Blackie Academic and Professional, New York, pp. 146, 198-200, 215.

Al-Mallah, A.Y. (1999). The Application into Kaolinite of the Economic Kaolin Clays (Permcarboniferous and Jurassic), in the Western Desert of Iraq, Ph. D., Thesis, The University of Mosul, College of Science, Geology Dept., pp.10, 39,123,137, 141-46, 159-60,188,196,197, 200, (Arabic).

Al-Najjar, Q. A. A. (2000). An Investigation of Using Locally Ninivite Rocks in Water Treatment. M. Sc. Thesis, Civil Engineering Department/ Environment, College of Engineering, The University of Mosul, pp. 42, 64, 75-77 (Arabic).

Al-Naqib, S. Q.; Mustafa, M. H. (1998). Preparation of new material from montmorillonitesmectite, to eliminate odors and spots. Iraqi patent No. 2710, Central System for Measurement and Quality Control, Baghdad, 11- 23, (Arabic).

Al-Ubaidy, N. H. T. (2004). Ninivite Silica Rocks Dopping with Chromium Oxide Gel,Physical and Structural Characterization and Application in Solid Phase Extraction Technique to Separate Virgin Iraqi Olive Oil. Ph.D. Thesis, College of Education University of Mosul, pp.55-56, (Arabic).

APHA, AWWA and WPCF. (1985). "Standard Methods for the Examination of Water and Wastewater", 16th edn., American Public Health Association, U.S.A., pp.157-160, 171.

Boynton, R.S., Editor (1980). "Chemistry and Technology of Lime and Limestone". A Wiley-Interscience Publication, USA., pp. 432-436.

Crear, R. (2001). "Engineering and Design, Precipitation/ Coagulation/ Flocculation", Manual No. 11101-1-4012, CECW-ET, Department of the Army U.S. Army Corps of Engineers Washington, DC 20314-1000, pp.1-1, 2-1, 2-2, 2-3, 2-5, 2-6, 3-2, 33,3-4, 3-5,3-6, 5-1, 5-2, 10-3.

Dyer, A.; Hudson, M.J. ; Williams, P.A.; Editors (1997). Progress in Ion Exchange Advanced and Applications, The Royal Society of Chemistry Information Service, U.K., pp. 48-52, 246-248.

Jeffery, P. G.; Hutchison, D. (1981). "Chemical Methods of Rock Analysis", Pergamon Press, New York, pp.22,30-42.

Kiley, G. (1997). "Environmental Engineering", Irwin- McGraw-Hill, UK., p53.

Krishnan, K.A.; Anirudhan, T.S. (2003). Removal of cadmium (II) from aqueous solutions by steam-activated sulphurised carbon prepared from sugar-cane bagasse pith: kinetics and equilibrium studies", Water SA, 29 (2), 147-155.

Available on website http://www.wreorg.za.

Lide, D.R. Editor, (1997-1998). "CRC HANDBOOK of Chemistry and Physics", 78th edn., pp.1-3, 5, 7, 9-11. 
Lindeburg, M. R. PE (2001). " Civil Engineering Reference Manual for the PE Exam", 8th edn., Professional Publications, Inc, Belmont, CA, U.S.A., pp. 25-4, 6, 32-2.

Liu, D.; Sansalone, J.J.; Cartledge, F.K.; Kolich, J. (2001). Divalent heavy metal removal using manganese oxide coated polymeric media for storm water treatment", WER and WEFTEC Research Symposium, pp. 23-27.

Masschelein, W.J. (1992). "Unit Processes in Drinking Water Treatment". Marcel Dekker, Inc. New York, pp. 453-454, 426-427, 453-454, and 459-461.

Meeravali, N. N.; Kumar, S. J. (2000). Comparison of open microwave digestion and digestion by conventional heating for the determination of $\mathrm{Cd}, \mathrm{Cr}, \mathrm{Cu}$ and $\mathrm{Pb}$ in algae using transverse heated electrothermal atomic absorption spectrometry, Fresenius . J. Anal. Chem., 366 (3), 313-5.

Muni, A. A. K. (2001). "Protection and Improvement of Factories Environment", 2nd edn., Dar Al-Harf Al-Arabie Print, Baghdad, pp. 67, 69, 72, (Arabic).

Mustafa, M.H. (2005). The Use of Mixed Ninivite and Kaolin for the Removal of Cd, $\mathrm{Hg}$, and $\mathrm{Pb}$ from Their Waste Water. $\mathrm{Ph}$. D. thesis in the field of Environmental Analytical Chemistry, The University of Mosul, College of Science, Chemistry Department,.

Mustafa, M. H. (2009). Tigris river grey water sources, impacts and suggested water treatment plants, Proceedings of The Ist Scientific and Environmental Conference, March, 30-31, The University of Mosul, College of Environmental Science and Technology.

Mustafa, M.H. (2002). The use of aluminum hydroxide as an alternative coagulant to basic lead acetate in sugar analyses, Iraqi patent No.3083, International Classification CO7H1/08, Iraqi Classification: 3 .

Nagata, N.; Kubota, L.T.;. Bueno, M.I.M.S; Peralta-Zamora, P.G. (2001). Adsorption parameters of $\mathrm{Cd}$ (II), $\mathrm{Pb}$ (II), and $\mathrm{Hg}$ (II) on Zirconium (IV) phosphate chemically grafted onto silica gel surface. J. Colloid. Interface Sci., 200, 121-125.

Rashed, M.N. (2003). Fruit stones as adsorbents for the removal of lead ion from polluted water. 1-13. www.eeaa.gov.eg/nglish/main/Env2003/Day2/water/rashed.uniasman.

Reddy, A.R.; Reddy, K. H. (2003). Heavy metal ion uptake properties of polystyrenesupported chelating polymer resins. Proc. Indian Acad. Sci. (Chem. Sci.), 115(3), 156-159.

Stanitski, C.L.; Edunanks, L. P.; Middlecamp, C. H.; Stratton, W. J. (2000). "Chemistry in Context, Applying Chemistry to Society". 3rd edn., Mc-Graw Hill, UK., pp. 206, 214-217.

Sullivan, D.J; Shore, J. S.; Rice, J.A. (2000). ${ }^{113}$ Cd double-resonance NMR as a probe of clay mineral cation exchange sites. American Mineralogist, 85, 1022-27.

Wang, F.; Tessier, A. (2002). Post-depositional mobility of trace elements in northern forest ecosystems. Annual Symposium Abstracts, University of Guelph, QU. Canada, pp. 3-4.

WHO, (1997). "International Program on Chemical Safety, Guidelines for Drinking-Water Quality". 2nd, edn., Health Criteria and Other Supporting Information, Eastern Mediterranean Regional Office, (CEHA) Al-Kssandaria, Egypt 2, pp. 4, 16-18, 20 22, 24-27. 